\title{
Cerebral Vascular Accidents (CVA) Victims Conception and Birth Time-Links to Longevity, Lithuania, 1989-2013
}

\author{
E. Stoupel1,2, J. Petrauskiene' ${ }^{3}$, R. Kalediene ${ }^{3}$, S. Sauliune ${ }^{3}$, E. Abramson ${ }^{4}$ \\ ${ }^{1}$ Division of Cardiology, Rabin Medical Center, Tel Aviv University, Petah Tiqwa, Israel \\ ${ }^{2}$ Sackler Faculty of Medicine, Tel Aviv University, Petah Tiqwa, Israel \\ ${ }^{3}$ Department of Medical Management, Lithuanian University of Medical Sciences, \\ Kaunas, Lithuania \\ ${ }^{4}$ Management Data Center, Rabin Medical Center, Petah Tiqwa, Israel \\ Email: stoupel@inter.net.il
}

Received 25 December 2014; accepted 20 January 2015; published 27 January 2015

Copyright (C) 2015 by authors and Scientific Research Publishing Inc.

This work is licensed under the Creative Commons Attribution International License (CC BY). http://creativecommons.org/licenses/by/4.0/

c) (i) Open Access

\section{Abstract}

In year 2001 a paper in the ANAS considered links between month of birth and longevity. In the following years we published four papers related to "big killers" (cardiac and oncology) that showed some differences in birth months distribution of this group and studied by LA, NS Gavrilov's centenarians. The aim of this study was to study conception and birth months of another modern "big killer"-cerebral stroke (CVA) that is taking a leading role among cardiovascular causes of death in the last decades. Methods: 130,120 deaths of both gender CVA victims in Lithuania at 1989-2013 were studied. In addition to birth month, the months of conception (9 months before birth) were studied. Our data were compared with results of centenarians (birth of LA, NS Gavrilov's study and transformed by authors also their conception month). Results: The maximum of births were January, March and May for CVA victims, while the analogical conception maximum were in April, June, May and July. The similar data for centenarians were that maximal births were in November, September, October (LA, NS Gavrilov) and conception in December, January, February. These results are similar to data related to cardiac and oncology deaths published in our previous publications. Conclusion: The conception and birth month of victims of CVA is different of similar data obtained by centenarians study. Different environmental conditions at different parts of the year and solar cycle can play a role affecting the embryo at early stages of development, predisposing to some pathologies in coming years of life. 


\section{Keywords}

\section{Time, Conception, Birth, Stroke, CVA, Longevity, Big, Killers}

\section{Introduction}

Time is "the final judge", the principal tool between man and environment.

In year 2001 in Annals of the National Academy of Science (USA) a study was published considering human longevity links with month of birth [1]. As a result of this study our groups published papers in the Ischemic Heart Disease (IHD), Myocardial Infarction (AMI), Rapid (agony time $\leq 24$ h) (RCD) and Sudden Cardiac Death (agony time $\leq 1 \mathrm{~h}$ ) (SCD) and another potential leader in human mortality-Oncology malignancies comparing these patients birth month with analogical data found by A. and N. Gavrilov's in their study of US 1574 centenarians (100 - 112-year-old people [2]—as a cohort of longevity population [3]-[7].

The aim of this study was to compare this very old people's birth month with birth month of another "big killer" that is taking a more and more leading position in Cardiovascular Medicine-brain Stroke, or Cerebral Vascular Accident (CVA). In addition to birth month we also included in this study the presumed conception month of both compared groups. The conception procedure was done after our studies in Congenital Heart Disease and Down Syndrome links with cosmophysical factors activity show that correlation of these abnormalities with Space Weather components (Solar, Geomagnetic, Cosmic Ray (Neutron)) activity is stronger at the month of presumed conception, than at the month of birth [8]-[11].

\section{Patients and Methods}

The included patient population was from the Republic of Lithuania that we have a long tradition of scientific cooperation - that were victims of CVA for 25 years-1989-2013 in Lithuania 132,020 people; in this study were included 130,120 patients - CVA victims that there month of birth was established. 81,320 woman and 48,800 men CVA victims were studied. The conception time was presumed 9 months before the birth month. Monthly conception and birth months were established for the total studied population also for each gender and compared with the mentioned 100 - 112-year group [2].

\section{Results}

Figures 1-3 presents conception month distribution for CVA victims total and male, female patients in percent. Figures 4-6 present the birth month distribution for the same population. The maximal conception and birth

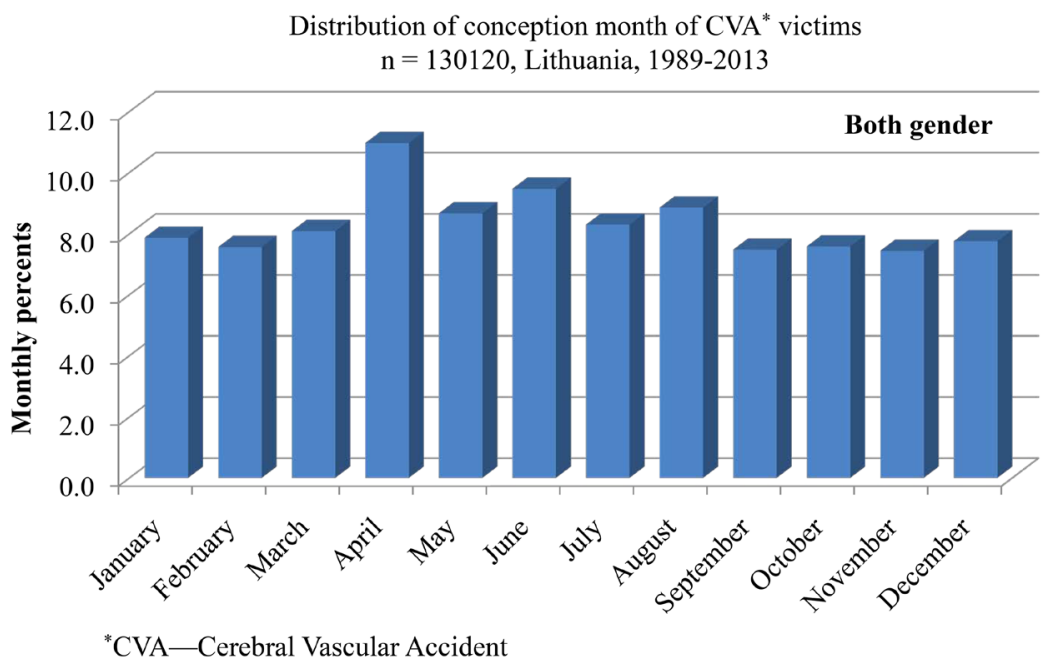

Figure 1. Monthly conception time of CVA victims. Both genders. 


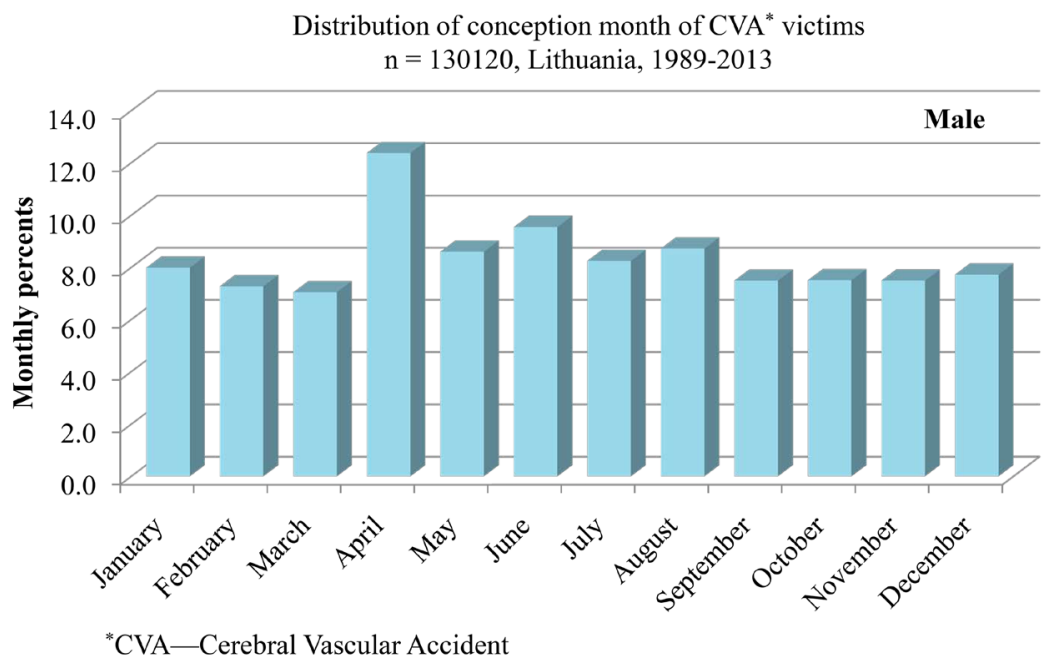

Figure 2. Monthly conception time of CVA victims. Male.

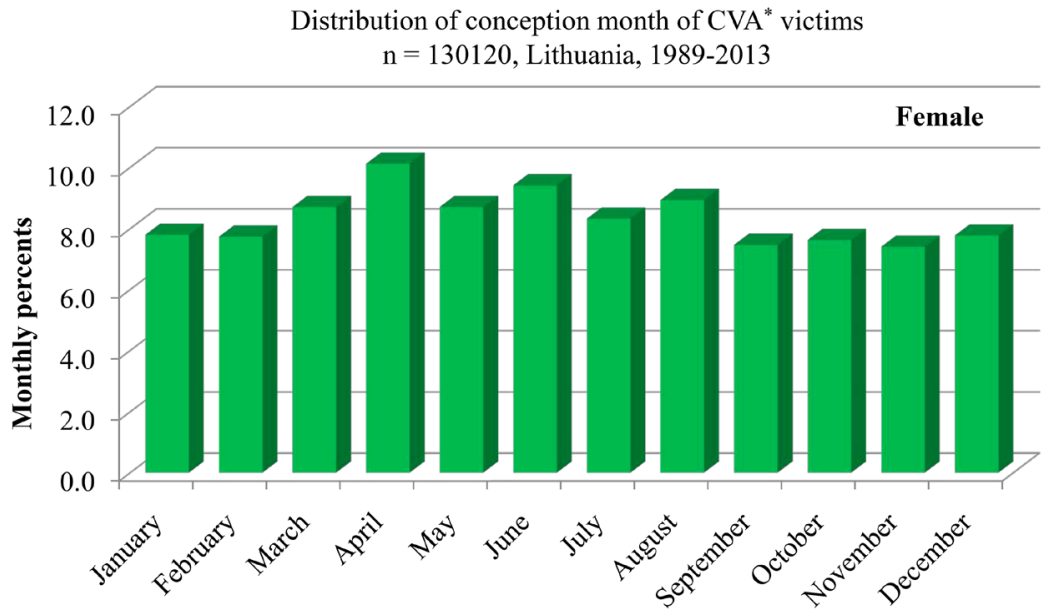

${ }^{*} \mathrm{CVA}$ - Cerebral Vascular Accident

Figure 3. Monthly conception time of CVA victims. Female.

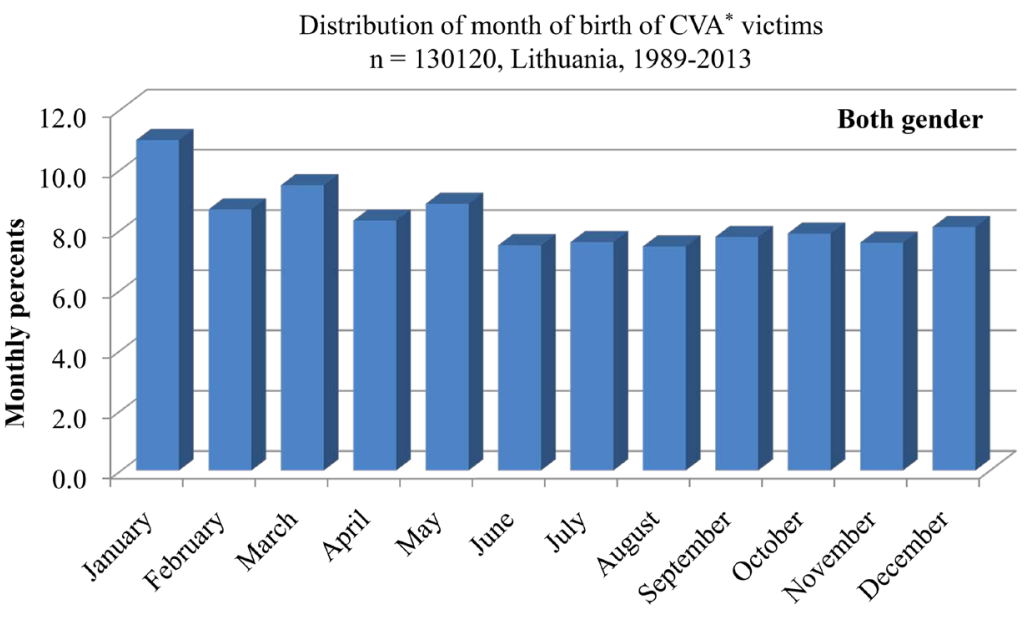

${ }^{*} \mathrm{CVA}$ - Cerebral Vascular Accident

Figure 4. Monthly birth time of CVA victims. Both genders. 


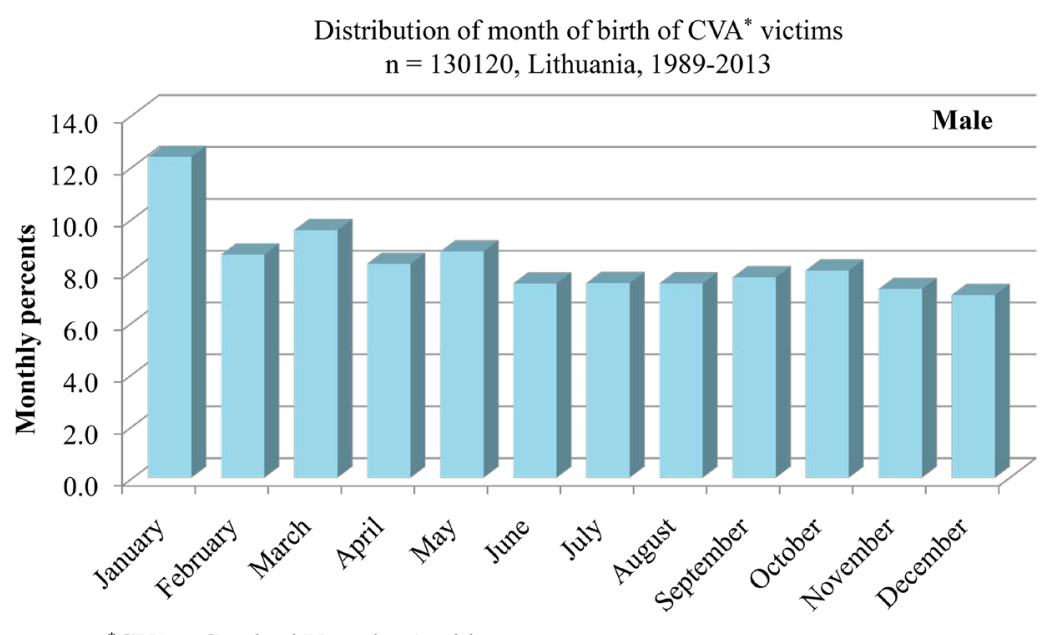

${ }^{*} \mathrm{CVA}$ - Cerebral Vascular Accident

Figure 5. Monthly bith time of CVA victims. Male.

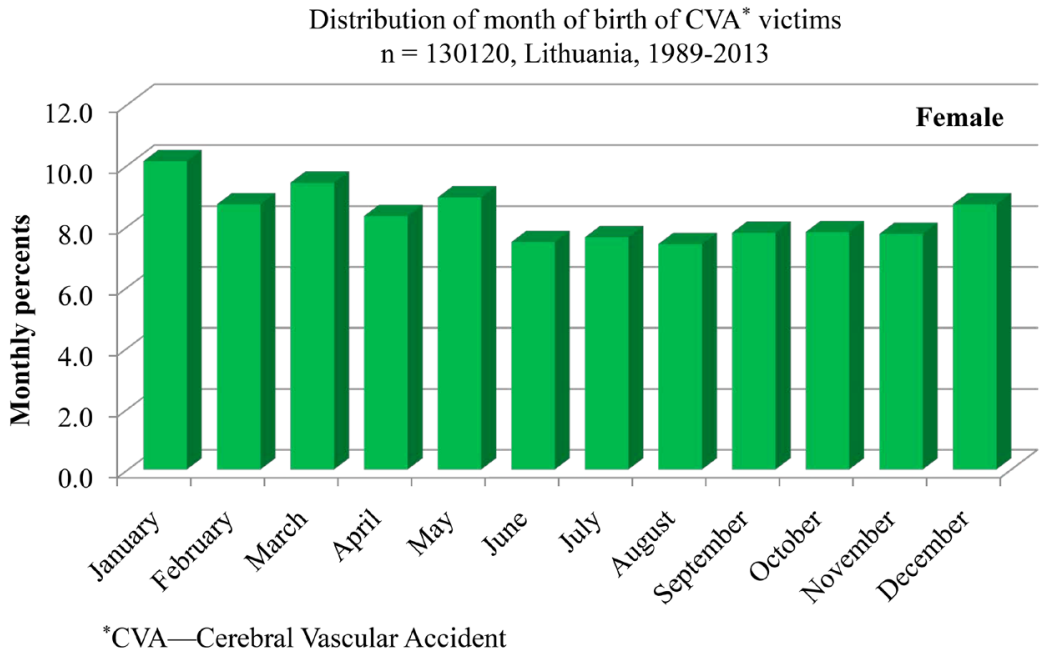

Figure 6. Monthly birth time of CVA victims. Female.

months distribution in the Gavrilov's [2] studied centenarians are as follows: for conception January, February, December. For birth months-November, September, October.

\section{Discussion}

Comparing the results of CVA victims conception and birth time with analogical study of acute cardiac events and oncology malignancies patients (all leading death causes in the industrial world) we can see many similarities: for all the maximal conception months were April, June, July, births concentrated at the first half of the year. The centenarian conception at the end of the year (December) and in January, February [2] [8] [9].

Here we must remind that the sun is closest to the Earth at January 3rd, most far on July 4th. Difference in distance about five million kilometers [10] [11]. Solar wind changes can affect many enzyme activities, involved in human physiology and pathology [12]. It's possible that such effects differ at different parts of solar cycle.

Changes in the early life stages can affect predisposition to specific pathologies, or their risk factors in the years coming.

In the last years it was announced that also in rats longevity was related to month of birth [13] [14]. The proposed mechanism of such changes can be related to different Melatonin production in different light intensity and time (Melatonin is produced only in dark) at months of the year and some effects of solar and geomagnetic 
activity [14].

Anyway it's a remarkable difference between all "big killers" population with the data seen in the centenarian group [7]. The seen differences returning us the old backgrounds of astrology, were many human life aspects were connected with the month of his/her birth [15]-[17]. Not only birth time has it rules. Human death is also rhythmic and deaths from different causes have different rhythms [18]. A special discipline Chronobiology is studying time related problems of our life [19]. The possible differences in human body related to different time of conception and birth can be a field of future studies.

Limitation of the study: Our presumption of conception time 9 months before birth month is ignoring about $10 \%$ preterm births. This can make some correction in our calculation, but not too much.

We not made different study for hemorrhagic and Ischemic stroke. But in modern society Ischemic stroke is the dominant form of the disease. The hemorrhagic stroke was more often before modern treatment of hypertension came.

\section{Conclusions}

The month of presumed conception and month of birth of victims of CVA are different from similar data of centenarians.

Possible environmental effects changing at different parts of the year can be involved in predisposition to specific risk factors and pathology in later stages of human life. But this demands additional studies.

\section{References}

[1] Doblhammer, G. and Vaupel, J.W. (2001) Lifespan Depends on Month of Birth. Proceedings of the National Academy of Science of the United States of America, 98, 2934-2939. http://dx.doi.org/10.1073/pnas.041431898

[2] Gavrilov, L.A. and Gavrilova, N.S. (2011) Season of Birth and Exceptional Longevity: Comparative Study of American Centenarians, Their Siblings and Spouses. Journal of Aging Research, 2011, Article ID: 104616. http://dx.doi.org/10.4061/2011/104616

[3] Stoupel, E., Abramson, E., Israelevich, P. and Sulkes, J. (2011) Birth Month and Longevity-Monthly Birth Distribution in Acute Coronary Events Provoked by Atherothrombosis in Patients Treated with Percutaneous Coronary Interventions (PCI). Journal of Basic and Clinical Physiology and Pharmacology, 22, 43-47.

[4] Stoupel, E., Tamoshiunas, A., Radishauskas, R., Bernotiene, G. and Abramson, E. (2011) Acute Myocardial Infarction in Context with the Paradigm-Month of Birth and Longevity. Health, 3, 1-6.

[5] Stoupel, E., Tamoshiunas, A., Radishauskas, R., Abramson, E., Bernotiene, G. and Bacevichiene, M. (2013) Birth Month and Longevity: Birth Month of Victims of Sudden (SCD, Agony Time $\leq 1 \mathrm{~h}$.) and Rapid ( RCD, Agony $\leq 24 \mathrm{~h}$ ) Cardiac Deaths. Journal of Basic and Clinical Physiology and Pharmacology, 24, 235-239. http://dx.doi.org/10.1515/jbcpp-2012-0075

[6] Stoupel, E., Abramson, E. and Fenig, E. (2012) Birth month of Patients with Malignant Neoplasms: Links to Longevity? Journal of Basic and Clinical Physiology and Pharmacology, 23, 57-60. http://dx.doi.org/10.1515/jbcpp-2012-0025

[7] Stoupel, E., Tamoshiunas, A., Radishauskas, R., Bernotiene, G., Assali, A., Vaknin, H., Teplitzki, I., Kornowski, R., Abramson, E. and Fenig, E. (2014) Time of Conception and Birth of the "Big Killer" Victims. Links to Longevity. Health, 6, 3062-3066. http://dx.doi.org/10.4236/health.2014.621346

[8] Stoupel, E., Birk, E., Kogan, A., Klinger, G., Abramson, E., Israelevich, P. and Sulkes, J. (2009) Congenital Heart Disease and Environmental Physical Activity, 1995-2005. International Journal of Cardiology, 135, 207-210. http://dx.doi.org/10.1016/j.ijcard.2008.03.053

[9] Stoupel, E., Frimer, H., Appelman, Z., Ben-Neriah, Z., Dar, H., Fejgin, M.D., et al. (2005) Chromosome Aberration and Environmental Physical Activity: Down Syndrome and Solar and Cosmic Ray Activity, Israel, 1990-2000. International Journal of Biometeorology, 50, 1-5. http://dx.doi.org/10.1007/s00484-005-0274-2

[10] Siuniayev, R. (Ed.) (1986) Physics of the Cosmos. Soviet Encyclopedia, Moscow, 569-572.

[11] Heckman (Ed.) (1988) SESC Glossary of Solar-Terrestrial Terms. Space Environment Service Center. Joint NOAAUSAF Environment Service Center, revised 1992, 1-63.

[12] Kirby, A.J. and Hellffelder, F. (2008) Enzymes under the Nanoscope. Nature, 456, 45-47. http://dx.doi.org/10.1038/456045a

[13] Bartsch, H., Bartsch, C., Mecke, D. and Lippert, T.H. (1994) Seasonality of Pineal Melatonin Production in the Rat: Possible Synchronization by the Geomagnetic Field. Chronobiology International, 11, 21-26. http://dx.doi.org/10.3109/07420529409057227 
[14] Bartsch, H., Kupper, H., Scheurlen, U., Deerberg, F., Seebald, E., Dietz, K., Mecke, D., Probst, H., Stehle, T. and Bartsch, C. (2010) Effect to a Chronic Exposure to a GSM-Like Signal (Mobile Phone) Survival of Female Sprague Dawley Rats: Modulatory Effects by Month of Birth and Stage of the Solar Cycle. Neuroendocrinology Letters, 31, 457-473.

[15] Halberg, F., Barnwell, F. and Hrushetsky, L.D. (1986) Chronobiology. A Science in Tune with the Rhythms of Life. Earl Bakken, Minneapolis, 1-20.

[16] Franz, M.-L. (1978) Time: Rhythm and Repose. Thames and Hudson, Golborn Lancashire, UK, Spain.

[17] Astrology, K.W. (1974) Avon, Publishers of Bard, Camelot, Discus, Exinox and Flair Books. Division of Hearst Corporation, London, 128p.

[18] Stoupel, E., Petrauskiene, J., Gabbay, U., Kalediene, R., Abramson, E. and Sulkes, J. (2001) Circannual Rhythmicity of Deaths Distribution. Acta Medica Lithuanica, 16, 37-42.

[19] Halberg, F. (2011) Chronobiology. Scholarpedia, 6, 3008. 
Scientific Research Publishing (SCIRP) is one of the largest Open Access journal publishers. It is currently publishing more than 200 open access, online, peer-reviewed journals covering a wide range of academic disciplines. SCIRP serves the worldwide academic communities and contributes to the progress and application of science with its publication.

Other selected journals from SCIRP are listed as below. Submit your manuscript to us via either submit@scirp.org or Online Submission Portal.
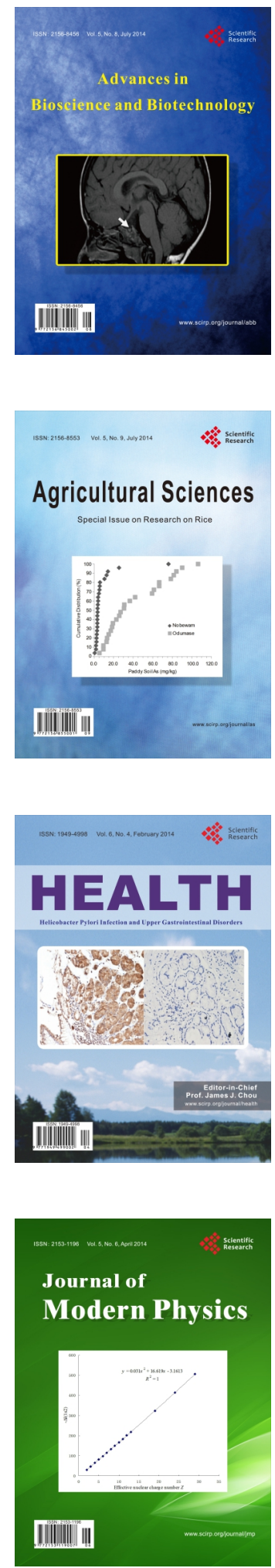
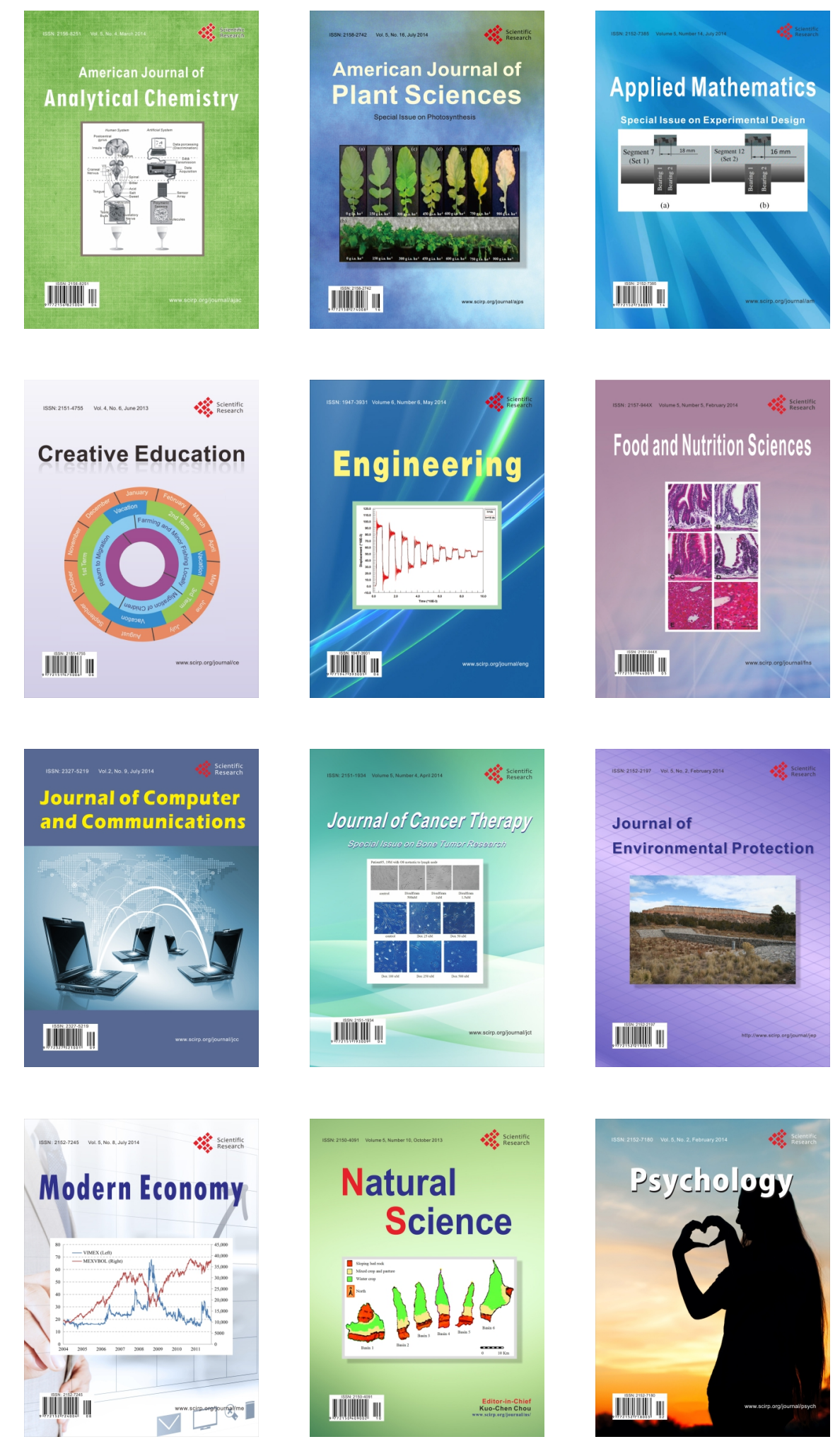